\title{
Gambaran Penggunaan Obat Analgetik secara Rasional dalam Swamedikasi pada Masyarakat PKS Balam, Desa Balai Jaya Km. 31 Kecamatan Balam Sempurna, Kabupaten Rokan Hilir, Riau
}

\author{
Lia Rahel Beniger Sipahutar ${ }^{1}$, Henny Erina Saurmauli Ompusunggu ${ }^{2}$, Runggu Retno J. Napitupulu ${ }^{3}$ \\ ${ }^{1}$ Mahasiswa Fakultas Kedokteran Universitas HKBP Nommensen \\ ${ }^{2}$ Departemen Biologi Sel dan Molekuler Fakultas Kedokteran Universitas HKBP Nommensen \\ ${ }^{3}$ Departemen Biologi Sel dan Molekuler Fakultas Kedokteran Universitas HKBP Nommensen \\ Korespondensi: Henny Erina Saurmauli Ompusunggu, Email: ompusunggu.henny@gmail.com
}

\begin{abstract}
Background: Analgesics are a type of medicine used to ease the sore. Certain types of analgesic drugs can be purchased by common people independently. This thing can be problematic if the analgesic drugs are not being used accordingly, the occurrence of unwanted side effects, for instance. The objective of this study is to find out an overview of analgesic drugs in self-medication towards the people of PKS Balam.
\end{abstract}

Methods: This study is a descriptive research. The respondents of this research are as many as 118 people of PKS Balam, which are chosen by using purpose sampling technique. An overview on the use of analgesic drugs in self-authentication in self-medication is acquired from questionnaire result.

Results: Majority of respondents who consume analgesic drugs by self-medicating more than once a month complain to experience most frequent headache. Most common analgesic drug consumed is paracetamol. Majority of respondents initially read the brochure of medicine they are about to consume, but most of them understand only some information provided in the brochure. Majority of respondents acquired analgesic drugs purchased from drugstore. The most experienced side effects after consuming analgesic drug is sleepiness. Due to limited level of knowledge, majority of respondents will stop consuming the medicines and go to see the doctor when they experience side effects.

Conclusion: The people of PKS Balam generally consume analgesic drugs by self-medicating more than once a month by initially reading the information about analgesic medicine they are about to consume.

Keywords: drug used, analgesic, self-medication

\begin{abstract}
Abstrak
Latar belakang: Analgetik merupakan obat yang digunakan untuk meredakan nyeri. Analgetik golongan tertentu dapat dibeli secara bebas oleh masyarakat. Hal ini dapat menjadi masalah apabila penggunaan analgetik tidak tepat, seperti timbulnya efek samping yang tidak diinginkan. Tujuan penelitian ini untuk mengetahui gambaran penggunaan analgetik secara rasional dalam swamedikasi pada masyarakat PKS Balam.

Metode: Penelitian ini merupakan penelitian deskriptif. Responden penelitian ini sebanyak 118 orang masyarakat PKS Balam, yang dipilih dengan tehnik purposive sampling. Gambaran penggunaan analgetik dalam swamedikasi diperoleh dari hasil kuesioner.

Hasil: Mayoritas responden mengkonsumsi analgetik secara swamedikasi lebih dari satu kali dalam sebulan dengan keluhan paling sering sakit kepala. Analgetik yang paling banyak digunakan adalah parasetamol. Mayoritas responden membaca terlebih dahulu brosur obat yang akan mereka minum, tapi mayoritas hanya paham
\end{abstract}


sebagian saja informasi yang terdapat pada brosur. Mayoritas responden memperoleh analgetik dengan membeli dari apotik. Efek samping yang paling dirasakan responden setelah mengkonsumsi analgetik adalah mengantuk. Keterbatasan tingkat pengetahuan menyebabkan mayoritas responden akan menghentikan penggunaan obat dan pergi ke dokter apabila merasakan efek samping.

Kesimpulan: Masyarakat PKS Balam pada umumnya mengkonsumsi analgetik secara swamedikasi lebih dari satu kali dalam sebulan dengan terlebih dahulu membaca informasi tentang analgetik yang akan mereka konsumsi.

Kata Kunci: Penggunaan obat, analgetik, swamedikasi

\section{Pendahuluan}

Analgetik adalah obat yang digunakan untuk mengurangi atau meredakan nyeri. Analgetik sering dikonsumsi untuk meredakan gejala seperti sakit kepala, sakit gigi, sakit saat menstruasi, nyeri otot, sakit perut, kelelahan dan lainnya. ${ }^{1,2}$ Analgetik dibagi menjadi dua kelompok, yaitu golongan opioid (narkotik) dan non-opioid. Analgetik golongan opioid dalam penggunaan berulang dapat menimbulkan ketergantungan dan toleransi. ${ }^{3}$ Analgetik non-opioid adalah analgetik yang tidak menimbulkan ketergantungan dan toleransi fisik. ${ }^{4}$

Persepsi seseorang terhadap rasa sakit dapat menentukan kapan dan bagaimana orang tersebut mengambil tindakan dalam pengobatan sendiri (swamedikasi). Penjualan obat-obatan secara bebas khususnya analgetik dapat dijadikan alternatif yang diambil masyarakat untuk meningkatkan keterjangkauan pengobatan, tetapi hal ini dapat menjadi sumber terjadinya kesalahan pengobatan karena keterbatasan pengetahuan masyarakat akan obat dan penggunaannya. ${ }^{5}$ Penelitian oleh Hallas dkk pada tahun 2009 di Denmark menyatakan 17 kasus pasien masuk rumah sakit mengalami gangguan saluran cerna oleh karena penggunaan NSAID (nonsteroidal anti-inflamatory drugs) dan 15 kasus di antaranya mengalami perdarahan akut. ${ }^{6}$ Penelitian lain yang dilakukan di Republik Serbia pada tahun 2004-2006 oleh Petric dkk juga menunjukkan peningkatan jumlah penggunaan NSAID (Ibuprofen dan Diklofenak) secara swamedikasi yang menyebabkan peningkatan kejadian kasus pasien masuk rumah sakit akibat gangguan pencernaan. ${ }^{7}$ Hal lain yang sering terjadi akibat penggunaan analgetik tidak sesuai anjuran adalah penglihatan kabur, perubahan uji fungsi hati, dan berkurangnya fungsi ginjal. ${ }^{4}$

Penelitian terhadap pelajar di Inggris oleh French dan James pada tahun 2007 menyatakan bahwa dari 271 responden, 73\% responden mengkonsumsi analgetik saat gejala mulai dirasakan, $40 \%$ responden mengkonsumsi lebih dari satu jenis analgetik. Berdasarkan frekuensi penggunaan analgetik untuk meredakan gejala nyeri, French dan James mendapatkan bahwa mayoritas reponden (58\%) "kadang" mengkonsumsi analgetik, 35\% responden "biasanya" mengkonsumsi analgetik, dan ada 7\% responden yang "selalu" mengkonsumsi analgetik. ${ }^{8}$ Penelitian tentang penyalahgunaan analgetik di Polandia oleh Wójta-Kempa dan Krzyżanowski pada tahun 2013 menyatakan bahwa dari 386 responden, hanya $2,3 \%$ responden yang membeli analgetik sesuai dengan resep dokter dan $6,2 \%$ responden yang tidak pernah membeli analgetik, 10,9\% responden mengkonsumsi analgetik setidaknya satu kali dalam seminggu, 18,9\% responden mengkonsumsi analgetik beberapa kali dalam sebulan dan $60,4 \%$ responden mengkonsumsi analgetik hanya dalam keadaan darurat. ${ }^{1}$

Penelitian oleh Taba pada tahun 2016 terhadap 211 masyarakat yang berkunjung ke Puskesmas Garuda di Bandung tentang profil penggunaan analgetik mendapatkan bahwa berdasarkan frekuensi konsumsi analgetik, 57,8\% responden (mayoritas) mengkonsumsi analgetik 2 kali dalam 6 bulan, 31,2\% responden mengkonsumsi analgetik 3-5 kali dalam 6 bulan dan sebanyak $11 \%$ responden mengkonsumsi analgetik lebih dari 5 kali dalam 6 bulan. Berdasarkan alasan penggunaan analgetik secara swamedikasi, sebanyak $62 \%$ responden menyatakan karena pengalaman kesembuhan oleh penggunaan obat nyeri sebelumnya, hemat waktu $29 \%$ responden, rekomendasi dokter saat berobat $17 \%$ responden dan rekomendasi tenaga kesehatan $16,1 \%$ responden. ${ }^{9}$

Ahmad pada tahun 2015 melakukan penelitian tentang penggunaan analgetik pada swamedikasi nyeri pada masyarakat kabupaten Demak. Hasil penelitian tersebut menyatakan bahwa dari 147 responden, $34 \%$ responden mengkonsumsi analgetik sampai rasa sakit hilang, $8 \%$ responden mengkonsumsi analgetik lebih dari satu minggu, $9 \%$ responden mengkonsumsi analgetik dalam 3-7 hari dan $49 \%$ responden mengkonsumsi analgetik kurang dari 3 hari. ${ }^{10} \mathrm{Ahmad}$ juga meneliti hubungan pengetahuan dengan penggunaan dan ketepatan pemilihan obat analgetik yang hasilnya menunjukkan bahwa responden yang memiliki pengetahuan baik cenderung lebih rasional menggunakan obat analgetik dibandingkan responden yang berpengetahuan kurang. ${ }^{10}$

Penelitian tentang hubungan pengetahuan, sikap dan perilaku terhadap swamedikasi penggunaan obat analgetik bebas pada para mahasiswa Sekolah Tinggi IImu Kesehatan Bina Husada oleh Kardewi pada tahun 2017 menyatakan tidak ada hubungan yang bermakna antara pengetahuan dan sikap terhadap swamedikasi, sedangkan antara perilaku dan swamedikasi didapati hubungan yang bermakna. ${ }^{11}$ Penelitian pengaruh pengetahuan terhadap perilaku swamedikasi obat anti inflamasi nonsteroid oral pada etnis Arab di Surabaya dilakukan oleh Hantoro dkk pada tahun 2012 menyatakan tidak dijumpai hubungan yang bermakna. ${ }^{12}$

Penelitian ini dilakukan dengan tujuan untuk mengetahui gambaran penggunaan obat analgetik secara rasional dalam swamedikasi pada masyarakat PKS Balam, desai Balai Jaya km. 31 kecamatan Balam Sempurna. Lingkungan masyarakat pada tempat penelitian merupakan lingkungan yang dibangun khusus untuk para karyawan yang dipekerjakan oleh suatu perusahaan, jam kerja yang padat, lingkungan yang terisolasi dan jarak yang 
jauh dari apotek serta minimnya tenaga medis menjadikan latar belakang penelitian ini dilakukan.

\section{Metode}

Penelitian ini dilaksanakan di PKS Balam, desa Balai Jaya km. 31 kecamatan Balam Sempurna, kabupaten Rokan Hilir, Riau pada bulan Maret - Mei 2020. Responden penelitian ini sebanyak 118 orang masyarakat PKS Balam, yang dipilih dengan teknik purposive sampling dengan metode pengambilan data yang dilakukan menggunakan data primer, yaitu kuesioner.

\section{Hasil}

Pada penelitian ini kelompok usia terbanyak pada umur 46-55 tahun $(61,2 \%)$, mayoritas responden adalah laki-laki $(97,75 \%)$ dengan pendidikan terakhir SMA (83,3\%) (Tabel 1).

\section{Tabel 1. Deskripsi Karakteristik Sampel}

\begin{tabular}{lll}
\hline Karakteristik & $\mathbf{N}$ & $\%$ \\
\hline Umur & & \\
17-25 tahun & 7 & 5,95 \\
26-35 tahun & 12 & 10,2 \\
36-45 tahun & 27 & 22,9 \\
46-55 tahun & 72 & 61,2 \\
Jenis Kelamin & & \\
Laki-laki & 115 & 97,75 \\
Perempuan & 3 & 2,55 \\
Pendidikan & & \\
SD & 1 & 0,85 \\
SMP & 11 & 9,35 \\
SMA & 98 & 83,3 \\
Perguruan tinggi & 8 & 6,8 \\
Penghasilan & & \\
<Rp 500.000 & 1 & 0,85 \\
Rp 500.000-1.000.000 & 0 & 0 \\
Rp 1.000.000-1.500.000 & 2 & 1,7 \\
Rp 1.500.000-2.000.000 & 8 & 6,8 \\
>Rp 2.000.000 & 107 & 90,95 \\
\hline
\end{tabular}

Hasil penelitian ini menunjukkan frekuensi konsumsi analgetik pada responden paling banyak lebih dari 1 kali dalam sebulan $(60,2 \%)$ dan ada juga responden yang mengkonsumsi analgetik setiap hari $(0,85 \%)$. Berdasarkan jenis analgetik yang dikonsumsi, paling banyak responden mengkonsumsi parasetamol $(83,9 \%)$. Berdasarkan indikasi mengkonsumsi analgetik, mayoritas responden mengkonsumsi analgetik bila mengalami keluhan sakit kepala $(72,9 \%)$, ada juga yang mengkonsumsi analgetik bila mengalami keluhan nyeri lainnya, seperti nyeri perut, sakit gigi, dan sebagainya. (Tabel 2).

Berdasarkan sumber informasi, responden paling banyak mendapat informasi tentang analgetik dari petugas kesehatan (70,3\%). Sebelum mengkonsumsi analgetik, mayoritas responden selalu membaca terlebih dahulu brosur informasi penggunaan obat analgetik $(60,2 \%)$, tetapi ada juga responden yang tidak pernah membaca brosur informasi penggunaan obat analgetik $(0,85 \%)$. Setelah membaca brosur informasi penggunaan obat analgetik, mayoritas responden hanya paham sebagian saja akan informasi yang tertulis pada brosur kemasan obat $(66,1 \%)$, bahkan ada yang tidak paham sama sekali $(0,85 \%)$. Berdasarkan cara memperoleh analgetik, mayoritas responden memperoleh analgetik dengan membeli dari apotek $(50,8 \%)$ dan berkonsultasi dengan dokter $(18,6 \%)$, tetapi ada juga yang memperoleh analgetik dengan membeli dari kedai ataupun diberikan oleh keluarga atau teman $(30,54 \%)$. (Tabel 2)

\section{Tabel 2. Gambaran Penggunaan Analgetik}

\begin{tabular}{|c|c|c|c|}
\hline No & $\begin{array}{c}\text { Pertanyaan } \\
\end{array}$ & $\mathbf{N}$ & $\%$ \\
\hline \multirow[t]{3}{*}{1} & Apakah saudara/i pernah mengkonsumsi analgetik? & & \\
\hline & Pernah & 118 & 100 \\
\hline & Tidak pernah & 0 & \\
\hline \multirow[t]{5}{*}{2} & Seberapa sering saudara/i mengkonsumsi analgetik? & & \\
\hline & Setiap hari & 1 & 0,85 \\
\hline & $\geq 1$ kali dalam seminggu & 12 & 10,2 \\
\hline & $\geq 1$ kali dalam sebulan & 71 & 60,2 \\
\hline & $\geq 1$ kali dalam setahun & 34 & 28,8 \\
\hline \multirow[t]{5}{*}{3} & Obat analgetik apa yang sering saudara/i gunakan? & & \\
\hline & Parasetamol & 99 & 83,9 \\
\hline & Asam mefenamat & 11 & 9,32 \\
\hline & Ibuprofen & 2 & 1,69 \\
\hline & Antalgin & 6 & 5,08 \\
\hline \multirow[t]{4}{*}{4} & Dari mana saudara/i mendapatkan informasi tentang analgetik? & & \\
\hline & Iklan media masa & 20 & 16,9 \\
\hline & Pengalaman keluarga/teman & 15 & 12,7 \\
\hline & Petugas kesehatan & 83 & 70,3 \\
\hline \multirow[t]{4}{*}{5} & $\begin{array}{l}\text { Apakah saudara/i membaca brosur informasi obat yang akan } \\
\text { digunakan? }\end{array}$ & & \\
\hline & Selalu & 71 & 60,2 \\
\hline & Kadang-kadang & 46 & 39 \\
\hline & Tidak Pernah & 1 & 0,85 \\
\hline \multirow[t]{4}{*}{6} & $\begin{array}{l}\text { Apakah saudara/i paham tentang informasi yang disampaikan pada } \\
\text { brosur obat yang akan digunakan? }\end{array}$ & & \\
\hline & Sangat paham & 38 & 33,05 \\
\hline & Hanya paham sebagian & 78 & 66,1 \\
\hline & Tidak paham sama sekali & 1 & 0,85 \\
\hline \multirow[t]{6}{*}{7} & Bagaimana biasanya saudara/i memperoleh analgetik? & & \\
\hline & Diberikan oleh keluarga/teman & 3 & 2,54 \\
\hline & Beli dari kedai dekat rumah & 33 & 28 \\
\hline & Apotek & 60 & 50,8 \\
\hline & Resep dokter & 22 & 18,6 \\
\hline & Dalam kondisi seperti apa saudara/i mengkonsumsi analgetik? & & \\
\hline \multirow[t]{5}{*}{8} & Sakit kepala & 86 & 72,9 \\
\hline & Sakit gigi & 20 & 16,9 \\
\hline & Sakit perut & 4 & 3,39 \\
\hline & Nyeri otot & 7 & 5,56 \\
\hline & Nyeri akibat trauma & 1 & 0,85 \\
\hline \multirow[t]{4}{*}{9} & $\begin{array}{l}\text { Efek apakah yang saudara/i rasakan setelah mengkonsumsi } \\
\text { analgetik? }\end{array}$ & & \\
\hline & Rasa sakit biasanya berkurang/sembuh & 95 & 80,5 \\
\hline & Rasa sakit kadang-kadang sembuh & 22 & 18,6 \\
\hline & Tidak ada perubahan & 1 & 0,85 \\
\hline \multirow[t]{6}{*}{10} & $\begin{array}{l}\text { Jika rasa sakit tidak juga berkurang/sembuh, apa yang saudara/i } \\
\text { lakukan? }\end{array}$ & & \\
\hline & Minum obat merek lain & 6 & 5,08 \\
\hline & Menambah dosis obat & 6 & 5,08 \\
\hline & Memakai obat tradisional & 5 & 4,24 \\
\hline & Pergi berobat ke dokter & 99 & 83,9 \\
\hline & Pergi berobat ke bidan & 1 & 0,85 \\
\hline \multirow[t]{3}{*}{11} & $\begin{array}{l}\text { Apakah saudara/i merasakan efek samping setelah mengkonsumsi } \\
\text { analgetik? }\end{array}$ & & \\
\hline & $\mathrm{Ya}$ & 71 & 60,2 \\
\hline & Tidak & 47 & 39,8 \\
\hline \multirow[t]{5}{*}{12} & Efek samping apa yang saudara/i rasakan? & & \\
\hline & Mengantuk & 61 & 85,9 \\
\hline & Jantung berdebar & 8 & 11,3 \\
\hline & Sakit perut & 1 & 1,41 \\
\hline & Gatal-gatal & 1 & 1,41 \\
\hline \multirow[t]{4}{*}{13} & Apa yang saudara/i lakukan jika mengalami efek samping tersebut? & & \\
\hline & $\begin{array}{l}\text { Berhenti mengkonsumsi analgetik, tetapi tidak pergi konsultasi ke } \\
\text { dokter }\end{array}$ & & 18,33 \\
\hline & $\begin{array}{l}\text { Berhenti mengkonsumsi analgetik dan mengkonsultasikan hal } \\
\text { tersebut dengan dokter }\end{array}$ & 147 & 66,2 \\
\hline & $\begin{array}{l}\text { Tetap mengkonsumsi obat tersebut karena sudah rutin } \\
\text { menggunakan obat tersebut }\end{array}$ & & 15,5 \\
\hline
\end{tabular}

Berdasarkan efek yang dirasakan setelah mengkonsumsi analgetik, mayoritas responden merasakan nyeri/ sakit berkurang atau sembuh setelah mengkonsumsi analgetik (80,5\%), tetapi ada juga responden yang tidak merasakan adanya perubahan setelah mengkonsumsi analgetik (0,85\%). Bila rasa sakit/ nyeri tidak 
berkurang setelah mengkonsumsi analgetik, mayoritas responden akan pergi berobat ke dokter $(83,9 \%)$, tetapi ada juga responden yang memilih untuk mengkonsumsi obat lainnya atau minum obat tradisional. (Tabel 2)

Berdasarkan ada atau tidaknya efek samping yang dirasakan responden setelah mengkonsumsi analgetik, didapati mayoritas responden merasakan efek samping setelah mengkonsumsi analgetik $(60,2 \%)$, dengan efek samping yang mayoritas responden rasakan adalah mengantuk (85,9\%). Bila merasakan efek samping setelah mengkonsumsi analgetik, mayoritas responden memilih berhenti mengkonsumsi analgetik dan berkonsultasi dengan dokter $(66,2 \%)$, tetapi ada juga responden yang tetap mengkonsumsi analgetik tersebut karena sudah rutin menggunakannya (15,5\%). (Tabel 2)

\section{Pembahasan}

Hasil penelitian ini menunjukkan frekuensi konsumsi analgetik pada responden paling banyak lebih dari 1 kali dalam sebulan dan ada juga responden yang mengkonsumsi analgetik setiap hari. Hasil ini sejalan dengan penelitian yang dilakukan oleh Steven dkk, yaitu mayoritas responden melakukan swamedikasi analgetik beberapa kali dalam sebulan. ${ }^{13}$ Agar obat dapat digunakan secara aman dan rasional, beberapa hal perlu diperhatikan seperti tepat indikasi, tepat pemilihan obat serta ketepatan dosis dan cara penggunaan obat. Peran apoteker atau tenaga kesehatan sangat diperlukan dalam edukasi pada masyarakat yang melakukan swamedikasi. ${ }^{5}$

Berdasarkan jenis analgetik yang dikonsumsi, paling banyak responden mengkonsumsi parasetamol. Hasil ini sejalan dengan penelitian yang dilakukan oleh Mutmaina dan Zulfebriges menunjukkan bahwa parasetamol adalah pilihan utama masyarakat dalam swamedikasi nyeri. ${ }^{14}$ Parasetamol merupakan obat anti nyeri golongan non opioid yang bekerja terutama pada sistem saraf pusat untuk menghambat pelepasan enzim siklooksigenase (COX) yang mengubah asam arakidonat menjadi prostaglandin, parasetamol adalah analgetik yang dapat digunakan untuk meredakan nyeri ringan hingga sedang dan juga merupakan obat antipiretik. Parasetamol merupakan golongan obat bebas yang dapat dibeli di apotek tanpa menggunakan resep dokter. 5,15

Berdasarkan indikasi mengkonsumsi analgetik, mayoritas responden mengkonsumsi analgetik bila mengalami keluhan sakit kepala. Hasil ini sejalan dengan penelitian yang dilakukan oleh Taba yaitu responden mengkonsumsi analgetik dengan keluhan terbanyak adalah sakit kepala. ${ }^{9}$ World Health Organization (WHO) juga melakukan penelitian yang difokuskan pada umur 18-65 tahun di 101 negara pada bulan Oktober 2006 sampai Maret 2009, menyatakan bahwa sebanyak $50-75 \%$ orang dewasa usia $18-65$ tahun di dunia mengalami sakit kepala selama setahun terakhir. ${ }^{16}$

Berdasarkan sumber informasi, responden paling banyak mendapat informasi tentang analgetik dari petugas kesehatan. Berbeda dengan hasil penelitian yang dilakukan oleh Kusuma menyatakan sumber informasi responden paling banyak mendapat informasi tentang analgetik adalah dari iklan. ${ }^{17}$ Sebelum mengkonsumsi analgetik, mayoritas responden selalu membaca terlebih dahulu brosur informasi penggunaan obat analgetik.
Penelitian yang dilakukan oleh Hilaria dan Maakh memiliki hasil yang sama dengan penelitian ini, yaitu mayoritas responden menjawab selalu membaca brosur informasi penggunaan obat; berbeda dengan penelitian yang dilakukan oleh Lutfiyati dkk, mayoritas responden menjawab jarang membaca brosur infomasi penggunaan obat. ${ }^{18,19}$ Sumber informasi mengenai penggunaan obat nyeri dalam swamedikasi seperti dosis, aturan pakai dan efek samping obat dapat diketahui dengan membaca informasi pada kemasan atau brosur obat sehingga dapat menghindari kesalahan pengobatan. ${ }^{5}$ Setelah membaca brosur informasi penggunaan obat analgetik, mayoritas responden hanya paham sebagian saja akan informasi yang tertulis pada brosur kemasan obat. Hasil ini tidak sejalan dengan penelitian yang dilakukan oleh Atmaja dan Rahmadina, mayoritas responden menjawab sangat paham akan informasi yang tertulis pada brosur kemasan obat. ${ }^{20}$ Hal ini dimungkinkan dengan informasi yang diberikan pada kemasan obat menggunakan istilah medis yang tidak dimengerti oleh masyarakat, informasi pada kemasan obat dan brosur obat sebaiknya menggunakan bahasa yang dimengerti oleh masyarakat sehingga dapat dijadikan informasi yang mendukung pengobatan yang rasional. ${ }^{21}$

Berdasarkan cara memperoleh analgetik, mayoritas responden memperoleh analgetik dengan membeli dari apotek dan berkonsultasi dengan dokter. Berbeda dengan hasil penelitian yang dilakukan oleh Mutmaina dan Zulfebriges, mayoritas responden memperoleh analgetik di warung. Faktor kemudahan untuk menjangkaunya merupakan alasan pemilihan warung sebagai tempat pembelian obat untuk swamedikasi. ${ }^{14}$

Berdasarkan efek yang dirasakan setelah mengkonsumsi analgetik, mayoritas responden merasakan nyeri/ sakit berkurang atau sembuh setelah mengkonsumsi analgetik. Berkurangnya rasa sakit yang dirasakan setelah mengkonsumsi analgetik diakibatkan dengan terhambatnya enzim COX dalam mensintesis asam arakidonat menjadi prostaglandin yang merupakan mediator inflamasi penyebab rasa sakit yang dirasakan. Bila rasa sakit/ nyeri tidak berkurang setelah mengkonsumsi analgetik, mayoritas responden akan pergi berobat ke dokter, tetapi ada juga responden yang memilih untuk mengkonsumsi obat lainnya atau minum obat tradisional. Hasil penelitian yang dilakukan oleh Kusuma juga menunjukkan hasil serupa, yaitu mayoritas responden menjawab berobat ke puskesmas jika rasa sakit tidak berkurang.

Berdasarkan ada atau tidaknya efek samping yang dirasakan responden setelah mengkonsumsi analgetik, didapati mayoritas responden merasakan efek samping setelah mengkonsumsi analgetik, dengan efek samping yang mayoritas responden rasakan adalah mengantuk. Berbeda dengan hasil yang didapatkan oleh Mutmaina dan Zulfebriges, mayoritas responden menjawab tidak merasakan efek samping apapun dan hanya sedikit responden yang merasakan mengantuk setelah mengkonsumsi analgetik. ${ }^{14}$ Efek samping yang terjadi tidak selalu memerlukan tindakan medis untuk mengatasinya. Meskipun demikian beberapa efek samping mungkin memerlukan perhatian lebih dalam penanganannya. Efek samping yang mungkin timbul antara lain reaksi alergi, gatal-gatal, ruam, mengantuk, mual dan lain-lain. Oleh karena itu penting untuk mengetahui efek samping 
obat yang dikonsumsi. ${ }^{22}$ Bila merasakan efek samping setelah mengkonsumsi analgetik, mayoritas responden memilih berhent mengkonsumsi analgetik dan berkonsultasi dengan dokter. Hasil ini sejalan dengan penelitian yang dilakukan oleh Kusuma, mayoritas responden memilih menghentikan pengobatan jika merasakan efek samping, namun hanya sedikit responden yang memilih berobat kedokter jika merasakan efek samping. ${ }^{17}$ Badan Pengawas Obat dan Makanan menyarankan jika mengalami efek samping setelah mengkonsumsi obat, segera hentikan pengobatan dan konsultasikan dengan petugas kesehatan. ${ }^{22}$ Jika pengobatan tetap dilanjutkan maka dapat menyebabkan gangguan saluran cerna, meningkatnya waktu perdarahan, penglihatan kabur, perubahan minor uji fungsi hati dan penggunaan dengan dosis yang berlebihan dapat menyebabkan berkurangnya fungsi ginjal. ${ }^{4}$

Lingkungan masyarakat pada tempat penelitian merupakan lingkungan yang dibangun khusus untuk para karyawan yang dipekerjakan oleh perusahaan sehingga terisolasi dari masyarakat lain, waktu tempuh yang diperlukan dari rumah warga ke apotek terdekat sekitar 20 menit dan \pm 1 jam menuju rumah sakit. Bagi karyawan, waktu keluar masuk lingkungan dibatasi pada pukul 20.00 dan kembali dibuka pukul 7.00. Jauhnya jarak tempuh antara rumah dengan apotek dan rumah sakit, serta terbatasnya waktu keluar dan masuk lingkungan perumahan dapat menjadi penyebab sedikitnya responden yang memilih berobat ke dokter jika merasakan efek samping.

\section{Kesimpulan}

Masyarakat PKS Balam pada umumnya mengkonsumsi analgetik secara swamedikasi lebih dari satu kali dalam sebulan dengan terlebih dahulu membaca informasi tentang analgetik yang akan mereka konsumsi.

\section{Daftar Pustaka}

1. Wójta-Kempa M, Krzyzanowski DM. Correlates of Abusing and Misusing over-the-Counter Pain Relievers among Adult Population of Wrocław (Poland). 2016;25(2):349-60.

2. Pottega A, Kviesgaard A-K, Hesse U, Moreno SI, Hansen JM. No Title. Patient Charact among Users Analg over-the-Counter Aspirin a Danish Pharm setting. 2014.

3. BPOM. In: informatorium Badan Pemeriksa Obat dan Makanan. edisi 20 Badan Pengawas Obat dan Makanan; 2014. hal. 378.

4. Price SA, Wilson LM. Patofisiologi. In: Patofisiologi Konsep Klinis ProsesProses Penyakit. edisi 6. 2015. hal. 1064-84.

5. Kemenkes RI. Pedoman Penggunaan Obat Bebas dan Bebas Terbatas. 2007;9-36.
6. Hallas J, Jensen KB, Grodum E, Damsbo N, Gram LF. Drug-Related Admissions to a Department of Medical Gastroenterology:1991;26(2):17480.

7. Petric M, Tasic L, Sukljevic S. Nonsteroidal Anti-Inflammatory Drug Usage and Gastrointestinal Outcomes in the Republic of Serbia. J Pain Palliat Care Pharmacother. 2009;23(1):40-7.

8. French DP, James DH. Reasons for the Use of Mild Analgesics Among English Students. 2008;30(1):79-85.

9. Taba K. Profil Penggunaan Obat Analgetik Tanpa Resep Dokter pada Masyarakat yang Berkunjung ke Puskesmas Garuda Kota Bandung [skripsi]. Politeknik Kesehatan Bandung. 2016.

10. Ahmad A. Hubungan Tingkat Pengetahuan dan Ketepatan Penggunaan Obat Analgetik pada Swamedikasi Nyeri di Masyarakat Demak [skripsi]. Universitas Muhammadiyah Surakarta. 2015.

11. Kardewi E. Hubungan Pengetahuan, Sikap dan Perilaku Terhadap Self Medication Penggunaan Obat Analgesik Bebas di Sekolah Tinggi IImu Kesehatan Bina Husada. SJM.2018;1(1):16-23.

12. Hantoro DT, Pristianty L, Athiyah U. Yuda A. Pengaruh Pengetahuan terhadap Perilaku Swamedikasi Obat Anti-Inflamasi Non-Steroid Oral pada Etnis Arab di Surabaya. JFK. 2017; 1(2):45-8

13. Steven VA, Antonius AP, Yosi IW. Profil Swamedikasi Analgesik di Masyarakat Surabaya, Jawa Timur [skripsi]. Universitas Surabaya. 2018.

14. Mutmaina UF, Zulfebriges. Gambaran Tingkat Pengetahuan Terhadap Penggunaan Obat Analgetik dalam Swamedikasi di Masyarakat Desa Rancabango Kabupaten Garut. Prosiding Farmasi.2019;5(2):526-33

15. Naumov DY, Vasilchenko MA, Howard JAK. Acetaminophen [internet]. $2020 . \quad$ Tersedia pada: https://pubchem.ncbi.nlm.nih.gov/compound/Acetaminophen

16. World Health Organization. Atlas of Headache Disorders and Resources in the World [internet]. 2011. Tersedia pada: https://www.who.int/mental_health/management/atlas_headache_disorder s/en/

17. Kusuma DPI. Hubungan Faktor Sosiodemografi dengan Tingkat Pengetahuan Swamedikasi Pada Masyarakat di Desa Sinduharjo Kabupaten Sleman [skripsi]. Universitas Islam Indonesia. 2019

18. Hilaria M, Maakh YF. Pemberdayaan Masyarakat Sebagai Aplikasi Gerakan Masyarakat Cerdas Menggunakan Obat.GEMASSIKA.2019;3(2):144-50

19. Lutfiyati H, Fitriana Y, Dianita PS. Pemberdayaan Kader PKK dalam Penerapan DAGUSIBU (Dapatkan, Gunakan, Simpan, dan Buang). Proceeding 6th University Research Colloquium 2017: Seri Pengabdian Kepada Masyarakat. 2017:9-14

20. Atmaja DS, Rahmadina A. Penggunaan Obat Rasional (POR) dalam Swamedikasi pada Tenaga Kesehatan di STIKES Sari Mulia Banjarmasin. J Pharmascience. 2019.

21. Kemenkes RI. Materi Pelatihan Peningkatan Pengetahuan dan Keterampilan Memilih Obat Bagi Tenaga Kesehatan. Jakarta.2008.

22. Badan Pengawas Obat dan Makanan. Menuju Swamedikasi yang Aman. Jakarta. 2014; $15: 4$ 